\title{
Examining the Dynamics of Macroeconomic Indicators and Banking Stock Returns with Bayesian Networks
}

\author{
Fatma Busem Hatipoglua ${ }^{\mathrm{a}}$ Umut Uyar $^{\mathrm{b}}$
}

Abstract: According to the modern portfolio theory, the direction of the relationship between the securities in the portfolio is stated to be effective in reducing the risk. Moreover, securities in high correlation are avoided by taking place in the same portfolio. The models structured by the Bayesian networks are capable of visually illustrate the probabilistic relationship. Also, portfolio returns could be refreshed simultaneously when new information has arrived. The study aims to provide dynamic information through Bayesian networks and to investigate the relationship between macroeconomic indicators and stock returns of Turkish major bank stocks based on the Arbitrage Pricing Model. The dataset includes stock returns of four banks listed in the Borsa Istanbul from June 2001 to January 2017. Besides, macroeconomic variables such as BIST-100 Index, oil prices, inflation, exchange, and interest rate \& money supply are gathered for the same period. The results suggest that the Bayesian network models allow dynamics among stock returns could be investigated in more detail. Additionally, it determines that macroeconomic variables would have various impacts on stock returns on bank stocks by comparison of the conventional methods.
Keywords: Arbitrage Pricing Model, Bayesian Networks, Machine Learning, Portfolio Selection Theory, Banking Stocks

JEL: C11, G11, G12

\section{Introduction}

The purpose of constructing portfolios is to gain returns from financial investments. According to Markowitz, diversification is not singly enough to reduce the risk level of a portfolio. The covariance coefficients between financial assets are also crucial. So, creating a balance between risk and return is essential for investors, when they are constructing their portfolios. In modern portfolio management, the investors aim to gain maximum return for a certain level of risk preference. Also, they take into account the historical movements and those movements are important for the asset return and market return relationship. However, neither modern nor traditional portfolio management theories do not have a systematic update feature. Bayesian network models not only have a systematic update feature but also they have a visualization feature for the linkage between asset returns.

Utilization from Bayesian networks in stock operations is particularly crucial for the circumstances experiencing fast-track changes and exhibiting immediate and sensitive response against sudden changes or incidents (Greppi, 2014: 85). In a Bayesian network, it is possible to refresh portfolio return distribution in case of entry of new information or evidence.

a PhD., Mugla Sitki Kocman University, Faculty of Economics and Administrative Sciences, Department of Business Administration, Mugla, Turkiye, busemh@gmail.com (ORCID ID: 0000-0001-5913-5290)

b Assoc. Prof., PhD., Pamukkale University, Faculty of Economics and Administrative Sciences, Department of Business Administration, Denizli, Turkiye, uuyar@pau.edu.tr (ORCID ID: 0000-0001-6217-8283) 
The study aims to investigate the impact of macroeconomic factors on bank stocks through the Bayesian network models based on the Arbitrage Pricing Model (APT) model. BIST-100 index (XU100), oil prices (PETROL), inflation rate (INF), USD/TRY exchange rate (USD/TRY), interest rate (INT) \& money supply and reciprocal items (M2) used as macroeconomic factors. Also, the stock returns of Garanti Bank (GARAN), Akbank (AKBNK), Is Bank (ISCTR) and Yapi Kredi Bank (YKBNK) are chosen as dependent variables. Expected returns are estimated by employing Bayesian network models.

In the next section of the study, the Turkish banking sector is discussed. In the third section, the relevant literature review is presented. In the fourth section, after the detailed information on dataset and method, obtained findings will be discussed. In the result section, findings regarding utilization from the Bayesian Network models and quantitative and qualitative information will be given.

\section{The Turkish Banking Sector}

Turkey which has a strategic location is a hub for many banks. According to the World Bank database, the country is an emerging country. Allied to the investment potentials of Turkey, many private and government oriented banks are operating in this emerging market. Domestic and foreign investors remark investment opportunities for many years. Foreign bank giants, especially the ones based in the Gulf Region, do have a massive hunger for buying Turkish banks (Market, 2018).

By the end of 2015, there are a total of 47 banks operating in the Turkish banking sector. They could be clustered into two main groups according to the Banks Association of Turkey: Deposit banks, and development and investment banks (BAT, 2017). Also, deposit banks may be examined under four types, namely "state-owned", "privately-owned", "foreign" banks, and "banks under The Savings Deposit Insurance Fund" (Ozkan, Cakan \& Kayacan, 2017). While 34 of the banks are deposit type, the number of development and investment banks are 13. There are three state-owned, nine privately-owned, 21 foreign banks in Turkey banking sector, although, only one bank is under The Savings Deposit Insurance Fund. As reported by The Banking System in Turkey Yearly Statistics 2017, the total number of branches including foreign branches is 10,781 , and the number of employees 196,699 in the banking system.

When the balance sheet data is focused on the Turkish banking system, the total assets of all banks is $\$ 737,482$ million in 2017 . The sources of that amount are deposits, non-deposit funds, and shareholders' equity; $56 \%, 25 \%, 11 \%$, respectively. When income statement data is examined for all banks in Turkey, the net profit account of all banks is $\$ 10,350$ million for 2016. Although, the net interest income/expense account is $\$ 25,592$ million, the net operating profit of all banks $\$ 12,607$ million in the same year.

Four major banks are analyzed in this paper which are Garanti Bank (GARAN), Akbank (AKBNK), Is Bank (ISCTR) and Yapi Kredi Bank (YKBNK). Turkiye Garanti Bankasi A.S. was established as a privately owned commercial bank in Ankara on April 25, 1946. The shares were having been traded in Borsa Istanbul, since June 6, 1990. General Electric Group bought 25.5 percent of shares of the bank to on December 22, 2005, and Banco Bilbao Vizcaya Argentaria SA (BBVA) acquired 24.89 percent of the bank on March 22, 2011. Till 2015, BBVA rose its shares to 39.90 percent and became the "dominant partner" of the bank, thus the bank transferred from the privately owned deposit banks group to foreign banks group. Akbank T.A.S. was founded in Adana on January 30,1948. The shares were started to be traded in the Istanbul Stock Exchange, since July 26, 1990. Some of the shares were also having traded in international markets since 1998. Akbank and Citibank Overseas Investment Corporation have completed the strategic partnership agreement according to which Citigroup acquired a 20 percent equity stake in Akbank, dated December 6, 2006. Turkiye Is Bankasi A.S. was founded on August 26, 1924. The shares are having traded both in Borsa Istanbul and in London Stock Exchange since May 4, 1998. Yapi Kredi Bankasi A.S. was founded on September 9, 1944. The shares of the bank were having traded since May 28, 1987, in Borsa Istanbul. Koc Financial Services decided to acquire 57.4 percent shares of the bank in May 2005 (BAT, 2017).

Those banks are selected for analysis in this paper because they have the highest four sector share of Turkey banking sector place. The sector shares percentages regarding assets of ISCTR, GARAN, AKBNK, and YKBNK are 12.0\%, 10.9\%, 10.4\%, and 9.7\%, respectively (BAT, 2017). 


\section{Literature Review}

According to modern portfolio management, it is not a wise choice to add highly correlated financial assets in a single portfolio. Bayes network models use learning algorithms which consider the financial assets' complex structure of covariance for constructing portfolios. In the literature of portfolio management, it is not possible to find a methodology which updates the asset weights in a portfolio when a piece of new information arrived in the market. On the other hand, Bayesian network models have an update feature, and it provides to visualize and calculate the possibilities between assets for new information. The pioneering researchers C. Shenoy and P. Shenoy (1998) showed how to create Bayesian networks between asset returns and risks the first time. Moreover, Tseng (2003) found that Bayesian network system, C5.0 Rule base system and a feed-forward neural network system perform better on portfolio construction than the modern portfolio management when new information arrived in the market.

Demirer, Mau and Shenoy (2006) suggested in their study that personal stocks analysts and portfolio managers could employ Bayesian network models in their decision-making process. In their study conducted on biomedical device manufacturing industry, return estimation of stocks of four companies in a portfolio and their relationship with economic factors are correlated employing Bayesian network models. Besides, Olbryś (2009) established correlations among macroeconomic variables, market sub-indexes and variables related to stocks of construction companies and portfolio return variables through Bayesian network models. In the study of Olbryś which evaluated various scenarios, it is reported that portfolio return and portfolio risk results obtained by using Bayesian network models display parallel findings with the study of Elton and Gruber (1981). Villa and Stella (2012) investigate the interaction between Modern Portfolio theory and Bayesian network models regarding portfolio analysis and optimization. Greppi, Giuli and Tarantola (2013) examined historical data through Bayesian network models; and included in fundamental analysis approach factors as well as market variables into the model. In their study which employed quarterly accounting and market data since 1990, authors concluded that Bayesian network models are a useful tool in the selection of financial assets. Further, Greppi (2014) organized macroeconomic factors, stocks variables, the weight of stocks and portfolio returns in a hierarchical order by utilizing from Bayesian network model; then conducted scenario analyses by adding updates on circumstances related with variables. Moreover, Hoe (2014) concluded that machine learning could assist portfolio managers and investors in the selection of stocks for portfolio risk analysis.

\section{Data and Methodology}

In the study, monthly stock returns of 4 banks that operate uninterruptedly in Borsa Istanbul National-100 (BIST-100) index for 2001-2016 periods is examined using Bayesian network models. Macroeconomic variables of the study were determined in the light of the variable used by the researchers conducted similar studies. In the current literature, especially the study of Chen, Roll and Ross (1986) has been referred frequently; and additionally, numbers of studies (Alizedeh, 2013; Ozer, Kaya \& Ozer, 2011; Kwon \& Shin, 1999; Kearney \& Daly, 1998; Chan, Chen \& Hsieh, 1985; Burmeister \& Wall, 1986; Clare \& Thomas, 1994; Chen \& Jordan, 1993; Beenstock \& Chan, 1988; Altay, 2005; Burmeister \& MacElroy, 1988) considered these variables as crucial variables. Data employed in the present study was collected from the official websites of the Organization for Economic Cooperation and Development (OECD), The Turkish Republic Central Bank (TCMB) and Bloomberg Professional Terminal Database.

Bayesian networks are graphical network models which allow exhibition of probability correlations as a directed acyclic graph $G=(V, A)$ of a random variable set $X=\left\{X_{1}, X_{2}, \ldots, X_{p}\right\}$. Whereas each node $v_{i} \in$ $V$ corresponds to the random variable of $X_{i}, A$ refers arcs (Nagarajan, Scutari \& Lebre, 2013: 13; Mittal \& Kassim, 2007: 15). Bayesian networks are comprised of a set of nodes representing random variables and a series of directed arcs which usually indicates causal relationships and represents probability dependencies (Bensi, Kiureghian \& Straub, 2011: 16).

Bayesian networks are constituted of two parts of qualitative and quantitative. In Bayesian networks bearing the form of the Directed Acyclic Graph (DAG), a graphical illustration of causal relationships among 
nodes constitutes a qualitative (structural) aspect of the network (Trucco, Cagno, Ruggeri \& Grande, 2008: 825). The quantitative aspect of the model is the learning parameter, and conditional probabilities of nodes whose parents are given (conditional probabilistic tables-CPT) are required to be learned (Sammut and Webb, 2011: 585). This parameter learning is the conditional probabilities of each nodes when parent nodes of the graph are given (Sucar, 2015: 106).

Chain rule refers to joint probability distribution on all variables marginally represented by Bayesian network's directed acyclic graph, and it allows estimation of conditional probabilities for each node of the network. If $X$ is the universe of the variables $X=\left\{X_{1}, X_{2}, \ldots, X_{n}\right\}$, the joint probability distribution of $X$ is given in Equation 1.

$$
P(X)=\sum_{i=1}^{n-1} P\left(X_{i} \mid X_{i+1}, \ldots, X_{n}\right)
$$

Joint probability distribution $P(X)$ enables the estimation of various marginal and conditional probabilities such as $P\left(X_{i}\right), P\left(X_{i} \mid X_{j}\right)$, and $P\left(X_{i} \mid e\right)$. At this point, in general, $e$ refers evidence: $e=$ $\left\{e_{1}, e_{2}, \ldots, e_{m}\right\}$, that is an information received from external sources about the possible states/values of a subset of the variables of the network (Trucco et al., 2008: 825).

The states which add new evidence into the network, update the distribution of the series used. For a series of discrete variable $X_{i}$, evidence seem probability distribution on states of $X_{i}$. If an observation is given regarding some variables of the network, the probability of some incidents could be estimated based on evidence:

$$
P(X \mid e)=\frac{P(X, e)}{P(e)}
$$

For states of variables, pieces of evidence are described in one of the states of variables either as soft or hard evidence for the nature of information whether it is given in indefinite or definite observation, respectively (Trucco et al., 2008, 826). Hard evidence means knowledge that some variable definitely has a particular value. It is also called a positive finding. However, soft evidence can be interpreted as evidence of uncertainty (Valtorta et al., 2002; Mrad et al., 2012). So, if there is a new piece of information or knowledge arises into the system, it should be hard evidence. On the other hand, if there is an event that comes up and increases uncertainty, it should be soft evidence.

It is possible to describe the Bayesian network analysis with the following steps:

Step 1: Concerning practical aspect, first, logarithmic returns of bank stocks prices were estimated; then, whereas the Market Model estimated monthly OLS regression residuals (referred as company-specific risks as well); expected the OLS regression analysis estimated returns of stocks. In the market model, the BIST 100 index is considered as the basis for market return $\left(R_{m t}\right)$. First of all, approximate $\alpha_{i}, \beta_{i}$ and residual values were estimated for each stock; then, estimations were added back into the regression model so that stocks return estimations could be calculated based on Market Model in Equation 3 below:

$$
\hat{R}_{t}=\hat{\alpha}_{i}+\hat{\beta}_{i} R_{m t}+\hat{e}_{t}
$$

Step 2: In the preceding step in the analysis process, by the APT Model in Equation 4, the stock of each bank was associated with macroeconomic factors as they were illustrated in Figure 1, 2, 3, and 4, respectively.

$$
R_{t}=\beta_{0}+\beta_{1} R_{m}+\beta_{2} F_{1}+\cdots+\beta_{n} F_{n}
$$


Figure 1. Bayesian Network Model (Garanti Bank)

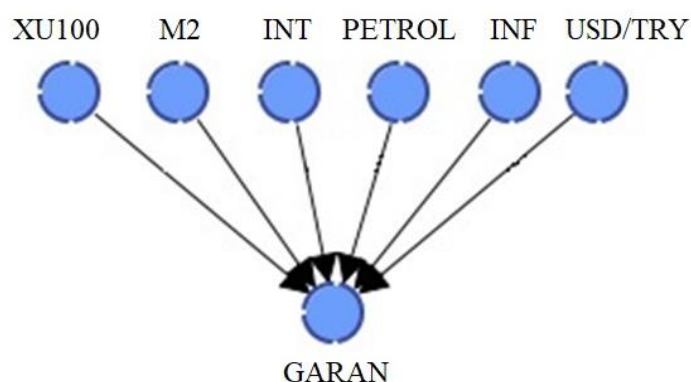

Figure 2. Bayesian Network Model (Akbank)

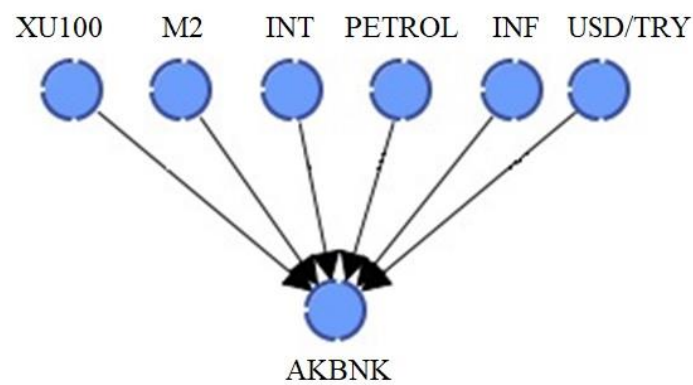

Figure 3. Bayesian Network Model (Is Bank)

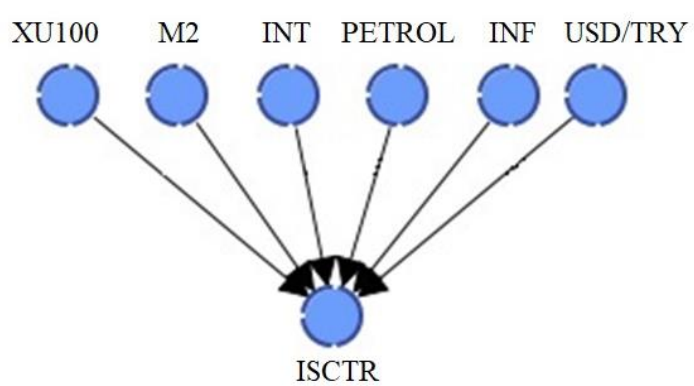

Figure 4. Bayesian Network Model (Yapi Kredi Bank)

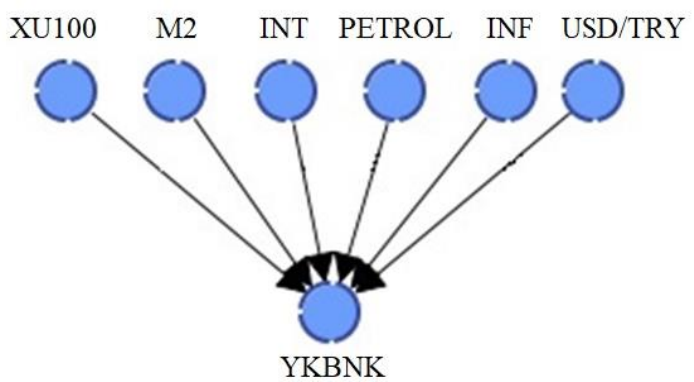

Step 3: In the next step, continuous variables of the study were discretized into three states through $K$-means data clustering algorithm by considering the current number of observations to transform them into a discrete variable. Step 4: In the analysis stage of the network, Kullback Leibler Divergence (KLD) function utilized for measuring the significance of the linear relationship between two probability distributions was 
employed. KLD allows comparison of two probability distributions of $P$ and $Q . P$, together with the arc, is Bayesian network; and $Q$ has no arc (Conrady \& Jouffe, 2015: 181).

$$
D_{K L}(P(X) \mid Q(X))=\sum_{X} P(X) \log _{2} \frac{P(X)}{Q(X)}
$$

Step 5: In the final stage of the analysis, macroeconomic variables were attached to hard evidences and findings were assessed.

One of the most important features that distinguish Bayesian networks from traditional methods is that they can examine the relationship between a large number of variables (5-10-100...), visualize the distribution of the returns, and simultaneous the variables in the network when new evidence comes. Due to those features of Bayesian network models, they provide better perspectives and outcomes when the relationship between variables is dynamic. BayesiaLab 6.0.7 software, which combines Bayesian network features with advanced diagram technology, was used in the application phase of the study.

\section{Empirical Findings and Discussion}

The study data set is comprised of stock return series of four banks quoted uninterruptedly in the BIST-100 index for the period between June 2001 and January 2017 (188 months), BIST-100 Index, oil prices and macroeconomic factors such as inflation rate, USD/TRY exchange rate, interest rate and money supply (M2). Analyses conducted in an order mentioned in the Method section.

Table 1. Beta Values of Stocks Prices

\begin{tabular}{lcccc}
\hline & GARAN & AKBNK & ISCTR & YKBNK \\
\hline $\boldsymbol{\alpha}$ & 0.012 & -0.009 & 0.005 & 0.005 \\
XU100 & $1.278^{*}$ & $1.002^{*}$ & $1.164^{*}$ & $1.260^{*}$ \\
M2 & $-5.582 E-12$ & $-6.975 E-12$ & $3.454 E-12$ & $1.152 E-11$ \\
INT & -0.005 & 0.023 & 0.016 & 0.038 \\
PETROL & -0.054 & -0.063 & -0.085 & -0.055 \\
INF & 0.009 & 0.042 & -0.071 & -0.076 \\
USD/TRY & 0.001 & 0.001 & 0.001 & 0.001 \\
\hline
\end{tabular}

$*, * *, * * *$ refers statistical significance levels of $1 \%, 5 \%$ and $10 \%$, respectively.

Since stocks are trading in the BIST, stocks included in the portfolio are theoretically and directly related. According to Table 1, bank stocks in the portfolio display response with the positive financial beta to the changes observed in the BIST financial beta. According to the coefficients obtained by the models in Equation 3 and 4 and by using OLS regression analysis method, the macroeconomic variables of the APT model was not statistically significant. The models only showed a statistically significant coefficient with XU100 return.

Table 2 exhibits the values estimated by using Kullback Leibler Divergence function allowing the significance of the direct relationship between two probability distributions. Hence, the most effective three macroeconomic variables on stock prices determined as XU100, M2 and interest rate. XU100 variable is the most influent factor on all stocks, and it satisfies the theoretical expectation. The fact that money supply and interest rate are both effective is considered as a result of the investigation of stocks from the banking industry. 
F. B. Hatipoglu - U. Uyar

Table 2. Kullback-Liebler Discretization Values between Bank Stocks and Macroeconomic Factors

\begin{tabular}{lcccc}
\hline & GARAN & AKBANK & ISCTR & YKBNK \\
\hline XU100 & 0.2643 & 0.2206 & 0.2711 & 0.1756 \\
M2 & 0.2151 & 0.1743 & 0.2024 & 0.1730 \\
INT & 0.1972 & 0.1600 & 0.1834 & 0.1540 \\
PETROL & 0.0928 & 0.0696 & 0.0934 & 0.0687 \\
INF & 0.0889 & 0.0757 & 0.0839 & 0.0756 \\
USD/TRY & 0.1437 & 0.1243 & 0.1463 & 0.1250 \\
\hline
\end{tabular}

Table 3. Descriptive Statistics and States of Bank Stocks

\begin{tabular}{|c|c|c|c|c|c|}
\hline Variable & \multicolumn{4}{|c|}{ States and intervals } & Probability Distribution \\
\hline \multirow{4}{*}{ GARAN } & \multicolumn{2}{|c|}{ States } & \multirow{2}{*}{$\begin{array}{c}\text { Min } \\
-0.494 \\
\end{array}$} & \multirow{2}{*}{$\begin{array}{c}\text { Max } \\
-0.0626 \\
\end{array}$} & \multirow{4}{*}{ XU100, M2, INT, INF, USD/TRY shorten by index } \\
\hline & Low & $<=-0.063$ & & & \\
\hline & Medium & $<=0.097$ & -0.0626 & 0.0970 & \\
\hline & High & $>0.097$ & 0.0970 & 0.4174 & \\
\hline \multirow{4}{*}{ AKBNK } & \multicolumn{2}{|c|}{ States } & Min & Max & \multirow{4}{*}{ XU100, M2, INT, INF, USD/TRY shorten by index } \\
\hline & Low & $<=-0.039$ & -0.304 & -0.0385 & \\
\hline & Medium & $<=0.113$ & -0.0385 & 0.1131 & \\
\hline & High & $>0.113$ & 0.1131 & 0.4272 & \\
\hline \multirow{4}{*}{ ISCTR } & & ates & Min & Max & \multirow{4}{*}{ XU100, M2, INT, INF, USD/TRY shorten by index } \\
\hline & Low & $<=-0.071$ & -0.4131 & -0.0713 & \\
\hline & Medium & $<=0.077$ & -0.0713 & 0.0765 & \\
\hline & High & $>0.077$ & 0.0765 & 0.3426 & \\
\hline \multirow{4}{*}{ YKBNK } & & ates & Min & Max & \multirow{4}{*}{ XU100, M2, INT, INF, USD/TRY shorten by index } \\
\hline & Low & $<=-0.129$ & -0.8128 & -0.1294 & \\
\hline & Medium & $<=0.058$ & -0.1294 & 0.0579 & \\
\hline & High & $>0.058$ & 0.05798 & 0.4878 & \\
\hline
\end{tabular}

Table 4. Macroeconomic Factors Descriptive Statistics and States

\begin{tabular}{|c|c|c|c|c|c|}
\hline Variable & \multicolumn{4}{|c|}{ States and intervals } & Probability Distribution \\
\hline \multirow{4}{*}{ XU100 } & \multicolumn{2}{|r|}{ States } & Min & Max & \multirow{4}{*}{ Marginal } \\
\hline & Low & $<=-0.034$ & -0.2629 & -0.0336 & \\
\hline & Medium & $<=0.079$ & -0.0336 & 0.0786 & \\
\hline & High & $>0.079$ & 0.0786 & 0.2603 & \\
\hline \multirow{4}{*}{ M2 } & \multicolumn{2}{|r|}{ States } & Min & Max & \multirow{4}{*}{ Marginal } \\
\hline & Low & $<=362867996.904$ & 38282033 & 362867996.90434 & \\
\hline & Medium & $<=835986666.506$ & 362867996.90434 & 835986666.50624 & \\
\hline & High & $>835986666.506$ & 835986666.50624 & 1426495420 & \\
\hline \multirow{4}{*}{ INT } & \multicolumn{2}{|r|}{ States } & Min & Max & \multirow{4}{*}{ Marginal } \\
\hline & Low & $<=0.119$ & 0.015 & 0.1192 & \\
\hline & Medium & $<=0.342$ & 0.1192 & 0.3415 & \\
\hline & High & $>0.342$ & 0.3415 & 0.6534 & \\
\hline \multirow{4}{*}{ PETROL } & \multicolumn{2}{|r|}{ States } & Min & Max & \multirow{4}{*}{ Marginal } \\
\hline & Low & $<=-0.063$ & -0.3948 & -0.0630 & \\
\hline & Medium & $<=0.046$ & -0.0630 & 0.0462 & \\
\hline & High & $>0.046$ & 0.0462 & 0.2602 & \\
\hline \multirow{4}{*}{ INF } & \multicolumn{2}{|r|}{ States } & Min & Max & \multirow{4}{*}{ Marginal } \\
\hline & Low & $<=0.2$ & 0.0399 & 0.1998 & \\
\hline & Medium & $<=0.475$ & 0.1998 & 0.4748 & \\
\hline & High & $>0.475$ & 0.4748 & 0.7316 & \\
\hline \multirow{4}{*}{ USD/TRY } & & States & Min & Max & \multirow{4}{*}{ Marginal } \\
\hline & Low & $<=1.6905$ & 1.1705 & 1.6904 & \\
\hline & Medium & $<=2.4389$ & 1.6904 & 2.4388 & \\
\hline & High & $>2.4389$ & 2.4388 & 3.7504 & \\
\hline
\end{tabular}


The descriptive statistics for the banking sector stocks and macroeconomic factors are demonstrated in Table 3 and 4, respectively. The return series are discretized as low-medium-high cases (which are called states) according to k-means data clustering algorithm. XU100, M2, FAIZ, ENF, DOLAR represent the parent nodes; hence, conditional probability distribution details are also provided in Table 3.

Like in Table 3, the macroeconomic factor series are discretized as low-medium-high states. Since the factors have no parent nodes, probability distributions of these nodes refer to the marginal probability distribution.

Findings of the study which analyses the impact of individual macroeconomic variables on bank stocks return were presented in Table 5-10.

Table 5. The Impact of Entry of New Evidence into the XU100 Macroeconomic Factor on Expected Returns on GARANTI BANK, AKBANK, IS BANK and YAPI KREDI BANK Stocks

\begin{tabular}{|c|c|c|c|c|c|c|}
\hline & State & $\begin{array}{l}\text { Entering } \\
\text { Evidence }\end{array}$ & $\begin{array}{l}\text { GARAN } \\
\text { State }\end{array}$ & $\begin{array}{l}\text { Before Adding Evidence } \\
\text { (GARAN) }\end{array}$ & $\begin{array}{c}\text { After Adding Evidence } \\
\text { (GARAN) }\end{array}$ & $\begin{array}{c}\text { GARAN } \\
\text { Change (\%) }\end{array}$ \\
\hline \multirow{10}{*}{ XU100 } & \multirow{3}{*}{ Low } & \multirow{3}{*}{$\% 100$} & Low & 32.20 & 47.64 & 15.44 \\
\hline & & & Medium & 37.01 & 29.58 & -7.43 \\
\hline & & & High & 30.79 & 22.78 & -8.01 \\
\hline & \multirow{3}{*}{ Medium } & \multirow{3}{*}{$\% 100$} & Low & 32.20 & 25.54 & -6.66 \\
\hline & & & Medium & 37.01 & 45.81 & 8.8 \\
\hline & & & High & 30.79 & 28.65 & -2.14 \\
\hline & \multirow{3}{*}{ High } & \multirow{3}{*}{$\% 100$} & Low & 32.20 & 24.80 & -7.4 \\
\hline & & & Medium & 37.01 & 27.53 & -9.48 \\
\hline & & & High & 30.79 & 47.67 & 16.88 \\
\hline & State & $\begin{array}{l}\text { Entering } \\
\text { Evidence }\end{array}$ & $\begin{array}{l}\text { AKBNK } \\
\text { State }\end{array}$ & $\begin{array}{l}\text { Before Adding Evidence } \\
\text { (AKBNK) }\end{array}$ & $\begin{array}{l}\text { After Adding Evidence } \\
\text { (AKBNK) }\end{array}$ & $\begin{array}{c}\text { AKBNK } \\
\text { Change (\%) }\end{array}$ \\
\hline \multirow{10}{*}{ XU100 } & \multirow{3}{*}{ Low } & \multirow{3}{*}{$\% 100$} & Low & 33.63 & 49.16 & 15.53 \\
\hline & & & Medium & 38.24 & 27.94 & -10.3 \\
\hline & & & High & 28.13 & 22.90 & -5.23 \\
\hline & \multirow{3}{*}{ Medium } & \multirow{3}{*}{$\% 100$} & Low & 33.63 & 27.52 & -6.11 \\
\hline & & & Medium & 38.24 & 46.35 & 8.11 \\
\hline & & & High & 28.13 & 26.13 & -2 \\
\hline & \multirow{3}{*}{ High } & \multirow{3}{*}{$\% 100$} & Low & 33.63 & 24.80 & -8.83 \\
\hline & & & Medium & 38.24 & 34.64 & -3.6 \\
\hline & & & High & 28.13 & 40.56 & 12.43 \\
\hline & State & $\begin{array}{l}\text { Entering } \\
\text { Evidence }\end{array}$ & $\begin{array}{l}\text { ISCTR } \\
\text { State }\end{array}$ & $\begin{array}{l}\text { Before Adding Evidence } \\
\text { (ISCTR) }\end{array}$ & $\begin{array}{l}\text { After Adding Evidence } \\
\text { (ISCTR) }\end{array}$ & $\begin{array}{c}\text { ISCTR } \\
\text { Change (\%) }\end{array}$ \\
\hline \multirow{10}{*}{ XU100 } & \multirow{3}{*}{ Low } & \multirow{3}{*}{$\% 100$} & Low & 31.56 & 46.34 & 14.78 \\
\hline & & & Medium & 37.41 & 30.92 & -6.49 \\
\hline & & & High & 31.03 & 22.74 & -8.29 \\
\hline & \multirow{3}{*}{ Medium } & \multirow{3}{*}{$\% 100$} & Low & 31.56 & 25.04 & -6.52 \\
\hline & & & Medium & 37.41 & 46.42 & 9.01 \\
\hline & & & High & 31.03 & 28.54 & -2.49 \\
\hline & \multirow{3}{*}{ High } & \multirow{3}{*}{$\% 100$} & Low & 31.56 & 24.80 & -6.76 \\
\hline & & & Medium & 37.41 & 26.01 & -11.4 \\
\hline & & & High & 31.03 & 49.19 & 18.16 \\
\hline & State & $\begin{array}{l}\text { Entering } \\
\text { Evidence }\end{array}$ & $\begin{array}{l}\text { YKBNK } \\
\text { State }\end{array}$ & $\begin{array}{l}\text { Before Adding Evidence } \\
\text { (YKBNK) }\end{array}$ & $\begin{array}{l}\text { After Adding Evidence } \\
\text { (YKBNK) }\end{array}$ & $\begin{array}{c}\text { YKBNK } \\
\text { Change (\%) }\end{array}$ \\
\hline \multirow{9}{*}{ XU100 } & \multirow{3}{*}{ Low } & \multirow{3}{*}{$\% 100$} & Low & 26.77 & 30.98 & 4.21 \\
\hline & & & Medium & 39.57 & 46.28 & 6.71 \\
\hline & & & High & 33.66 & 22.74 & -10.92 \\
\hline & \multirow{3}{*}{ Medium } & \multirow{3}{*}{$\% 100$} & Low & 26.77 & 24.96 & -1.81 \\
\hline & & & Medium & 39.57 & 41.17 & 1.6 \\
\hline & & & High & 33.66 & 33.87 & 0.21 \\
\hline & & & Low & 26.77 & 24.73 & -2.04 \\
\hline & High & $\% 100$ & Medium & 39.57 & 25.88 & -13.69 \\
\hline & & & High & 33.66 & 49.39 & 15.73 \\
\hline
\end{tabular}


According to Table 5, it says that all returns on banking stocks are influenced in the same way from the BIST-100 index. In case the decreasing probability of the XU100 index is $100 \%$, whereas the relevant decreasing probabilities of GARAN, AKBNK and ISCTR stock returns increases, the probability of maintaining the return on YKBNK stock on average increases. In case the probability of increasing XU100 index is $100 \%$, the probability of increasing all bank stocks increases as well. According to relationships among stock markets, the return of AKBNK stock is the one most affected by the decreasing probability of index, however, ISCTR stock is the one most affected by the increasing probability of the BIST Index. When it is considered together with the financial beta coefficients obtained from the market model in Equation 3 , it is obvious that Bayesian network models provide investors more detailed information on the relationship of stocks market and return.

Table 6. The Impact of Entry of Evidence into M2 Macroeconomic Factor on Expected Returns of GARANTI BANK, AKBANK, IS BANK and YAPI KREDI BANK Stocks

\begin{tabular}{|c|c|c|c|c|c|c|}
\hline & State & $\begin{array}{l}\text { Entering } \\
\text { Evidence }\end{array}$ & $\begin{array}{l}\text { GARAN } \\
\text { State }\end{array}$ & $\begin{array}{c}\text { Before Adding } \\
\text { Evidence (GARAN) }\end{array}$ & $\begin{array}{c}\text { After Adding Evidence } \\
\text { (GARAN) }\end{array}$ & $\begin{array}{c}\text { GARAN } \\
\text { Change (\%) }\end{array}$ \\
\hline \multirow{10}{*}{ M2 } & \multirow{3}{*}{ Low } & \multirow{3}{*}{$\% 100$} & Low & 32.20 & 31.32 & -0.88 \\
\hline & & & Medium & 37.01 & 36.34 & -0.67 \\
\hline & & & High & 30.79 & 32.35 & 1.56 \\
\hline & \multirow{3}{*}{ Medium } & \multirow{3}{*}{$\% 100$} & Low & 32.20 & 33.50 & 1.3 \\
\hline & & & Medium & 37.01 & 37.62 & 0.61 \\
\hline & & & High & 30.79 & 28.87 & -1.92 \\
\hline & \multirow{3}{*}{ High } & \multirow{3}{*}{$\% 100$} & Low & 32.20 & 31.91 & -0.29 \\
\hline & & & Medium & 37.01 & 37.36 & 0.35 \\
\hline & & & High & 30.79 & 30.73 & -0.06 \\
\hline & State & $\begin{array}{l}\text { Entering } \\
\text { Evidence }\end{array}$ & $\begin{array}{l}\text { AKBNK } \\
\text { State }\end{array}$ & $\begin{array}{c}\text { Before Adding } \\
\text { Evidence (AKBNK) }\end{array}$ & $\begin{array}{l}\text { After Adding Evidence } \\
\text { (AKBNK) }\end{array}$ & $\begin{array}{c}\text { AKBNK } \\
\text { Change (\%) }\end{array}$ \\
\hline \multirow{10}{*}{ M2 } & \multirow{3}{*}{ Low } & \multirow{3}{*}{$\% 100$} & Low & 33.63 & 32.44 & -1.19 \\
\hline & & & Medium & 38.24 & 36.56 & -1.68 \\
\hline & & & High & 28.13 & 31.00 & 2.87 \\
\hline & \multirow{3}{*}{ Medium } & \multirow{3}{*}{$\% 100$} & Low & 33.63 & 35.05 & 1.42 \\
\hline & & & Medium & 38.24 & 41.19 & 2.95 \\
\hline & & & High & 28.13 & 23.76 & -4.37 \\
\hline & \multirow{3}{*}{ High } & \multirow{3}{*}{$\% 100$} & Low & 33.63 & 33.74 & 0.11 \\
\hline & & & Medium & 38.24 & 36.91 & -1.33 \\
\hline & & & High & 28.13 & 29.35 & 1.22 \\
\hline & State & $\begin{array}{l}\text { Entering } \\
\text { Evidence }\end{array}$ & $\begin{array}{l}\text { ISCTR } \\
\text { State }\end{array}$ & $\begin{array}{l}\text { Before Adding } \\
\text { Evidence (ISCTR) }\end{array}$ & $\begin{array}{l}\text { After Adding Evidence } \\
\text { (ISCTR) }\end{array}$ & $\begin{array}{c}\text { ISCTR } \\
\text { Change (\%) }\end{array}$ \\
\hline \multirow{10}{*}{ M2 } & \multirow{3}{*}{ Low } & \multirow{3}{*}{$\% 100$} & Low & 31.56 & 30.92 & -0.64 \\
\hline & & & Medium & 37.41 & 36.20 & -1.21 \\
\hline & & & High & 31.03 & 32.88 & 1.85 \\
\hline & \multirow{3}{*}{ Medium } & \multirow{3}{*}{$\% 100$} & Low & 31.56 & 31.84 & 0.28 \\
\hline & & & Medium & 37.41 & 39.57 & 2.16 \\
\hline & & & High & 31.03 & 28.59 & -2.44 \\
\hline & \multirow{3}{*}{ High } & \multirow{3}{*}{$\% 100$} & Low & 31.56 & 32.36 & 0.8 \\
\hline & & & Medium & 37.41 & 36.39 & -1.02 \\
\hline & & & High & 31.03 & 31.25 & 0.22 \\
\hline & State & $\begin{array}{l}\text { Entering } \\
\text { Evidence }\end{array}$ & $\begin{array}{l}\text { YKBNK } \\
\text { State }\end{array}$ & $\begin{array}{c}\text { Before Adding } \\
\text { Evidence (YKBNK) }\end{array}$ & $\begin{array}{l}\text { After Adding Evidence } \\
\text { (YKBNK) }\end{array}$ & $\begin{array}{c}\text { YKBNK } \\
\text { Change (\%) }\end{array}$ \\
\hline \multirow{9}{*}{ M2 } & \multirow{3}{*}{ Low } & \multirow{3}{*}{$\% 100$} & Low & 26.77 & 28.34 & 1.57 \\
\hline & & & Medium & 39.57 & 37.21 & -2.36 \\
\hline & & & High & 33.66 & 34.44 & 0.78 \\
\hline & \multirow{3}{*}{ Medium } & \multirow{3}{*}{$\% 100$} & Low & 26.77 & 22.01 & -4.76 \\
\hline & & & Medium & 39.57 & 44.46 & 4.89 \\
\hline & & & High & 33.66 & 33.54 & -0.12 \\
\hline & & & Low & 26.77 & 31.11 & 4.34 \\
\hline & High & $\% 100$ & Medium & 39.57 & 36.56 & -3.01 \\
\hline & & & High & 33.66 & 32.33 & -1.33 \\
\hline
\end{tabular}


Table 6 presents the probability values estimated by Bayesian network models for the relationships between the money supply variable and the return of bank stocks. The preliminary findings suggest that money supply and returns of bank stocks are not correlated like XU100. In this relationship, returns on GARAN, AKBNK and ISCTR stocks are likely to increase when the probability of low level of the money supply is $100 \%$. On the other hand, return on YKBNK stocks is likely to decrease in the same circumstance. However, when the money supply is likely to increase by $100 \%$, it could be seen that probability of encountering lower returns on ISCTR and YKBNK stocks increase; as return on GARAN stock remains on an average level; the probability of increasing return on AKBNK stock increases. Findings indicate that banking stocks are influenced by $\mathrm{M} 2$ money supply at various levels. This situation is considered a result of various cash asset positions of individual banks. It says that different cash positions of banks have an effect on the profitability of banks, and accordingly, this influences their market values.

Table 7. The Impact of Entry of New Evidence into Interest Rate Macroeconomic Factor on Expected Returns of GARANTI BANK, AKBANK, IS BANK and YAPI KREDI BANK Stocks

\begin{tabular}{|c|c|c|c|c|c|c|}
\hline & State & $\begin{array}{l}\text { Entering } \\
\text { Evidence }\end{array}$ & $\begin{array}{l}\text { GARAN } \\
\text { State }\end{array}$ & $\begin{array}{c}\text { Before Adding } \\
\text { Evidence (GARAN) }\end{array}$ & $\begin{array}{l}\text { After Adding Evidence } \\
\text { (GARAN) }\end{array}$ & $\begin{array}{c}\text { GARAN } \\
\text { Change (\%) }\end{array}$ \\
\hline \multirow{10}{*}{ INT } & \multirow{3}{*}{ Low } & \multirow{3}{*}{$\% 100$} & Low & 32.20 & 31.11 & -1.09 \\
\hline & & & Medium & 37.01 & 40.48 & 3.47 \\
\hline & & & High & 30.79 & 28.41 & -2.38 \\
\hline & \multirow{3}{*}{ Medium } & \multirow{3}{*}{$\% 100$} & Low & 32.20 & 33.35 & 1.15 \\
\hline & & & Medium & 37.01 & 33.25 & -3.76 \\
\hline & & & High & 30.79 & 33.40 & 2.61 \\
\hline & \multirow{3}{*}{ High } & \multirow{3}{*}{$\% 100$} & Low & 32.20 & 33.25 & 1.05 \\
\hline & & & Medium & 37.01 & 34.02 & -2.99 \\
\hline & & & High & 30.79 & 32.73 & 1.94 \\
\hline & State & $\begin{array}{l}\text { Entering } \\
\text { Evidence }\end{array}$ & $\begin{array}{l}\text { AKBNK } \\
\text { State }\end{array}$ & $\begin{array}{c}\text { Before Adding } \\
\text { Evidence (AKBNK) }\end{array}$ & $\begin{array}{l}\text { After Adding Evidence } \\
\text { (AKBNK) }\end{array}$ & $\begin{array}{c}\text { AKBNK } \\
\text { Change (\%) }\end{array}$ \\
\hline \multirow{10}{*}{ INT } & \multirow{3}{*}{ Low } & \multirow{3}{*}{$\% 100$} & Low & 33.63 & 33.36 & -0.27 \\
\hline & & & Medium & 38.24 & 40.81 & 2.57 \\
\hline & & & High & 28.13 & 25.82 & -2.31 \\
\hline & \multirow{3}{*}{ Medium } & \multirow{3}{*}{$\% 100$} & Low & 33.63 & 34.01 & 0.38 \\
\hline & & & Medium & 38.24 & 36.62 & -1.62 \\
\hline & & & High & 28.13 & 29.37 & 1.24 \\
\hline & \multirow{3}{*}{ High } & \multirow{3}{*}{$\% 100$} & Low & 33.63 & 33.64 & 0.01 \\
\hline & & & Medium & 38.24 & 33.02 & -5.22 \\
\hline & & & High & 28.13 & 33.34 & 5.21 \\
\hline & State & $\begin{array}{l}\text { Entering } \\
\text { Evidence }\end{array}$ & $\begin{array}{l}\text { ISCTR } \\
\text { State }\end{array}$ & $\begin{array}{l}\text { Before Adding } \\
\text { Evidence (ISCTR) }\end{array}$ & $\begin{array}{l}\text { After Adding Evidence } \\
\text { (ISCTR) }\end{array}$ & $\begin{array}{c}\text { ISCTR } \\
\text { Change (\%) }\end{array}$ \\
\hline \multirow{10}{*}{ INT } & \multirow{3}{*}{ Low } & \multirow{3}{*}{$\% 100$} & Low & 31.56 & 30.75 & -0.81 \\
\hline & & & Medium & 37.41 & 39.28 & 1.87 \\
\hline & & & High & 31.03 & 29.97 & -1.06 \\
\hline & \multirow{3}{*}{ Medium } & \multirow{3}{*}{$\% 100$} & Low & 31.56 & 32.06 & 0.5 \\
\hline & & & Medium & 37.41 & 36.07 & -1.34 \\
\hline & & & High & 31.03 & 31.87 & 0.84 \\
\hline & \multirow{3}{*}{ High } & \multirow{3}{*}{$\% 100$} & Low & 31.56 & 33.24 & 1.68 \\
\hline & & & Medium & 37.41 & 34.00 & -3.41 \\
\hline & & & High & 31.03 & 32.76 & 1.73 \\
\hline & State & $\begin{array}{l}\text { Entering } \\
\text { Evidence }\end{array}$ & $\begin{array}{l}\text { YKBNK } \\
\text { State }\end{array}$ & $\begin{array}{c}\text { Before Adding } \\
\text { Evidence (YKBNK) }\end{array}$ & $\begin{array}{l}\text { After Adding Evidence } \\
\text { (YKBNK) }\end{array}$ & $\begin{array}{c}\text { YKBNK } \\
\text { Change (\%) }\end{array}$ \\
\hline \multirow{9}{*}{ INT } & \multirow{3}{*}{ Low } & \multirow{3}{*}{$\% 100$} & Low & 26.77 & 26.16 & -0.61 \\
\hline & & & Medium & 39.57 & 41.53 & 1.96 \\
\hline & & & High & 33.66 & 32.31 & -1.35 \\
\hline & \multirow{3}{*}{ Medium } & \multirow{3}{*}{$\% 100$} & Low & 26.77 & 25.27 & -1.5 \\
\hline & & & Medium & 39.57 & 39.08 & -0.49 \\
\hline & & & High & 33.66 & 35.65 & 1.99 \\
\hline & & & Low & 26.77 & 32.87 & 6.1 \\
\hline & High & $\% 100$ & Medium & 39.57 & 33.68 & -5.89 \\
\hline & & & High & 33.66 & 33.45 & -0.21 \\
\hline
\end{tabular}


According to Table 7, when the correlation between interest rate and returns of interested banking stocks is considered in detail, it could be seen that stock of each bank could be affected from interest rate changes at various levels. In case the rising probability of interest rate is $100 \%$, there is a higher probability of increasing returns on GARAN, AKBNK and ISCTR stocks. However, YKBNK returns exhibit an inverse relationship. In theory, a substitute relation and inverse impact are expected between interest rate and stock returns. However, the fact that stocks included in the analysis are from the banking industry suggests that an increase in their market value is an expected consequence because increasing interest rates positively affect their profitability. On the other hand, when the state in which the probability of decreasing interest rate is $100 \%$ is taken into consideration, it could be seen that probability of returns of all bank stocks remains on average level increases.

Table 8. The Impact of Entry of New Evidence into Oil Price Macroeconomic Factor on Expected Returns on GARANTI BANK, AKBANK, IS BANK and YAPI KREDI BANK Stocks

\begin{tabular}{|c|c|c|c|c|c|c|}
\hline & State & $\begin{array}{l}\text { Entering } \\
\text { Evidence }\end{array}$ & $\begin{array}{l}\text { GARAN } \\
\text { State }\end{array}$ & $\begin{array}{c}\text { Before Adding } \\
\text { Evidence (GARAN) }\end{array}$ & $\begin{array}{l}\text { After Adding Evidence } \\
\text { (GARAN) }\end{array}$ & $\begin{array}{c}\text { GARAN } \\
\text { Change (\%) }\end{array}$ \\
\hline \multirow{10}{*}{ PETROL } & \multirow{3}{*}{ Low } & \multirow{3}{*}{$\% 100$} & Low & 32.20 & 30.54 & -1.66 \\
\hline & & & Medium & 37.01 & 37.66 & 0.65 \\
\hline & & & High & 30.79 & 31.79 & 1 \\
\hline & \multirow{3}{*}{ Medium } & \multirow{3}{*}{$\% 100$} & Low & 32.20 & 31.12 & -1.08 \\
\hline & & & Medium & 37.01 & 39.67 & 2.66 \\
\hline & & & High & 30.79 & 29.22 & -1.57 \\
\hline & \multirow{3}{*}{ High } & \multirow{3}{*}{$\% 100$} & Low & 32.20 & 34.60 & 2.4 \\
\hline & & & Medium & 37.01 & 33.44 & -3.57 \\
\hline & & & High & 30.79 & 31.97 & 1.18 \\
\hline & State & $\begin{array}{l}\text { Entering } \\
\text { Evidence }\end{array}$ & $\begin{array}{l}\text { AKBNK } \\
\text { State }\end{array}$ & $\begin{array}{c}\text { Before Adding } \\
\text { Evidence (AKBNK) }\end{array}$ & $\begin{array}{l}\text { After Adding Evidence } \\
\text { (AKBNK) }\end{array}$ & $\begin{array}{c}\text { AKBNK } \\
\text { Change }(\%)\end{array}$ \\
\hline \multirow{10}{*}{ PETROL } & \multirow{3}{*}{ Low } & \multirow{3}{*}{$\% 100$} & Low & 33.63 & 32.05 & -1.58 \\
\hline & & & Medium & 38.24 & 38.91 & 0.67 \\
\hline & & & High & 28.13 & 29.04 & 0.91 \\
\hline & \multirow{3}{*}{ Medium } & \multirow{3}{*}{$\% 100$} & Low & 33.63 & 34.01 & 0.38 \\
\hline & & & Medium & 38.24 & 37.85 & -0.39 \\
\hline & & & High & 28.13 & 28.13 & 0 \\
\hline & \multirow{3}{*}{ High } & \multirow{3}{*}{$\% 100$} & Low & 33.63 & 34.23 & 0.6 \\
\hline & & & Medium & 38.24 & 38.25 & 0.01 \\
\hline & & & High & 28.13 & 27.51 & -0.62 \\
\hline & State & $\begin{array}{l}\text { Entering } \\
\text { Evidence }\end{array}$ & $\begin{array}{l}\text { ISCTR } \\
\text { State }\end{array}$ & $\begin{array}{l}\text { Before Adding } \\
\text { Evidence (ISCTR) }\end{array}$ & $\begin{array}{l}\text { After Adding Evidence } \\
\text { (ISCTR) }\end{array}$ & $\begin{array}{c}\text { ISCTR } \\
\text { Change (\%) }\end{array}$ \\
\hline \multirow{10}{*}{ PETROL } & \multirow{3}{*}{ Low } & \multirow{3}{*}{$\% 100$} & Low & 31.56 & 29.79 & -1.77 \\
\hline & & & Medium & 37.41 & 39.91 & 2.5 \\
\hline & & & High & 31.03 & 30.30 & -0.73 \\
\hline & \multirow{3}{*}{ Medium } & \multirow{3}{*}{$\% 100$} & Low & 31.56 & 33.62 & 2.06 \\
\hline & & & Medium & 37.41 & 35.47 & -1.94 \\
\hline & & & High & 31.03 & 30.92 & -0.11 \\
\hline & \multirow{3}{*}{ High } & \multirow{3}{*}{$\% 100$} & Low & 31.56 & 30.31 & -1.25 \\
\hline & & & Medium & 37.41 & 38.03 & 0.62 \\
\hline & & & High & 31.03 & 31.66 & 0.63 \\
\hline & State & $\begin{array}{l}\text { Entering } \\
\text { Evidence }\end{array}$ & $\begin{array}{l}\text { YKBNK } \\
\text { State }\end{array}$ & $\begin{array}{c}\text { Before Adding } \\
\text { Evidence (YKBNK) }\end{array}$ & $\begin{array}{l}\text { After Adding Evidence } \\
\text { (YKBNK) }\end{array}$ & $\begin{array}{c}\text { YKBNK } \\
\text { Change (\%) }\end{array}$ \\
\hline \multirow{9}{*}{ PETROL } & \multirow{3}{*}{ Low } & \multirow{3}{*}{$\% 100$} & Low & 26.77 & 27.42 & 0.65 \\
\hline & & & Medium & 39.57 & 37.18 & -2.39 \\
\hline & & & High & 33.66 & 35.40 & 1.74 \\
\hline & \multirow{3}{*}{ Medium } & \multirow{3}{*}{$\% 100$} & Low & 26.77 & 26.82 & 0.05 \\
\hline & & & Medium & 39.57 & 40.21 & 0.64 \\
\hline & & & High & 33.66 & 32.97 & -0.69 \\
\hline & & & Low & 26.77 & 26.27 & -0.5 \\
\hline & High & $\% 100$ & Medium & 39.57 & 40.41 & 0.84 \\
\hline & & & High & 33.66 & 33.31 & -0.35 \\
\hline
\end{tabular}


Since banks are not from manufacturing industry, an insignificant correlation is expected between oil prices and bank stocks. Thus, it is considered that oil prices would affect bank stocks at a limited extent. Based on the models exhibited in Table 8, for the case in which probability of decreasing oil prices is $100 \%$, it could be seen that there is a higher probability for increasing GARAN, AKBNK and YKBNK returns; a probability of maintaining ISCTR return on average level increases. On the contrary, in case of the probability of increasing oil price is $100 \%$, an increase could be seen with probabilities of decreasing returns on GARAN and AKBNK stocks, increasing return on ISCTR, and maintaining the return on YKBNK stock on the average level.

Table 9. The Impact of Entry of New Evidence into Inflation Rate Macroeconomic Factor on Expected Returns on GARANTI BANK, AKBANK, IS BANK and YAPI KREDI BANK Stocks

\begin{tabular}{|c|c|c|c|c|c|c|}
\hline & State & $\begin{array}{l}\text { Entering } \\
\text { Evidence }\end{array}$ & $\begin{array}{l}\text { GARAN } \\
\text { State }\end{array}$ & $\begin{array}{c}\text { Before Adding } \\
\text { Evidence (GARAN) }\end{array}$ & $\begin{array}{l}\text { After Adding Evidence } \\
\text { (GARAN) }\end{array}$ & $\begin{array}{c}\text { GARAN } \\
\text { Change }(\%)\end{array}$ \\
\hline \multirow{10}{*}{ INF } & \multirow{3}{*}{ Low } & \multirow{3}{*}{$\% 100$} & Low & 32.20 & 32.06 & -0.14 \\
\hline & & & Medium & 37.01 & 37.46 & 0.45 \\
\hline & & & High & 30.79 & 30.48 & -0.31 \\
\hline & \multirow{3}{*}{ Medium } & \multirow{3}{*}{$\% 100$} & Low & 32.20 & 32.73 & 0.53 \\
\hline & & & Medium & 37.01 & 34.91 & -2.1 \\
\hline & & & High & 30.79 & 32.36 & 1.57 \\
\hline & \multirow{3}{*}{ High } & \multirow{3}{*}{$\% 100$} & Low & 32.20 & 33.61 & 1.41 \\
\hline & & & Medium & 37.01 & 33.48 & -3.53 \\
\hline & & & High & 30.79 & 32.91 & 2.12 \\
\hline & State & $\begin{array}{l}\text { Entering } \\
\text { Evidence }\end{array}$ & $\begin{array}{l}\text { AKBNK } \\
\text { State }\end{array}$ & $\begin{array}{c}\text { Before Adding } \\
\text { Evidence (AKBNK) }\end{array}$ & $\begin{array}{l}\text { After Adding Evidence } \\
\text { (AKBNK) }\end{array}$ & $\begin{array}{c}\text { AKBNK } \\
\text { Change }(\%)\end{array}$ \\
\hline \multirow{10}{*}{ INF } & \multirow{3}{*}{ Low } & \multirow{3}{*}{$\% 100$} & Low & 33.63 & 33.66 & 0.03 \\
\hline & & & Medium & 38.24 & 39.06 & 0.82 \\
\hline & & & High & 28.13 & 27.28 & -0.85 \\
\hline & \multirow{3}{*}{ Medium } & \multirow{3}{*}{$\% 100$} & Low & 33.63 & 33.54 & -0.09 \\
\hline & & & Medium & 38.24 & 33.38 & -4.86 \\
\hline & & & High & 28.13 & 33.08 & 4.95 \\
\hline & \multirow{3}{*}{ High } & \multirow{3}{*}{$\% 100$} & Low & 33.63 & 33.33 & -0.3 \\
\hline & & & Medium & 38.24 & 33.35 & -4.89 \\
\hline & & & High & 28.13 & 33.32 & 5.19 \\
\hline & State & $\begin{array}{l}\text { Entering } \\
\text { Evidence }\end{array}$ & $\begin{array}{l}\text { ISCTR } \\
\text { State }\end{array}$ & $\begin{array}{l}\text { Before Adding } \\
\text { Evidence (ISCTR) }\end{array}$ & $\begin{array}{l}\text { After Adding Evidence } \\
\text { (ISCTR) }\end{array}$ & ISCTR Change (\%) \\
\hline \multirow{10}{*}{ INF } & \multirow{3}{*}{ Low } & \multirow{3}{*}{$\% 100$} & Low & 31.56 & 31.31 & -0.25 \\
\hline & & & Medium & 37.41 & 38.01 & 0.6 \\
\hline & & & High & 31.03 & 30.68 & -0.35 \\
\hline & \multirow{3}{*}{ Medium } & \multirow{3}{*}{$\% 100$} & Low & 31.56 & 32.76 & 1.2 \\
\hline & & & Medium & 37.41 & 33.81 & -3.6 \\
\hline & & & High & 31.03 & 33.43 & 2.4 \\
\hline & \multirow{3}{*}{ High } & \multirow{3}{*}{$\% 100$} & Low & 31.56 & 33.52 & 1.96 \\
\hline & & & Medium & 37.41 & 33.82 & -3.59 \\
\hline & & & High & 31.03 & 32.66 & 1.63 \\
\hline & State & $\begin{array}{l}\text { Entering } \\
\text { Evidence }\end{array}$ & $\begin{array}{l}\text { YKBNK } \\
\text { State }\end{array}$ & $\begin{array}{c}\text { Before Adding } \\
\text { Evidence (YKBNK) }\end{array}$ & $\begin{array}{l}\text { After Adding Evidence } \\
\text { (YKBNK) }\end{array}$ & $\begin{array}{c}\text { YKBNK } \\
\text { Change }(\%)\end{array}$ \\
\hline \multirow{9}{*}{ INF } & \multirow{3}{*}{ Low } & \multirow{3}{*}{$\% 100$} & Low & 26.77 & 25.77 & -1 \\
\hline & & & Medium & 39.57 & 40.51 & 0.94 \\
\hline & & & High & 33.66 & 33.72 & 0.06 \\
\hline & \multirow{3}{*}{ Medium } & \multirow{3}{*}{$\% 100$} & Low & 26.77 & 32.46 & 5.69 \\
\hline & & & Medium & 39.57 & 34.58 & -4.99 \\
\hline & & & High & 33.66 & 32.96 & -0.7 \\
\hline & & & Low & 26.77 & 33.09 & 6.32 \\
\hline & High & $\% 100$ & Medium & 39.57 & 33.16 & -6.41 \\
\hline & & & High & 33.66 & 33.75 & 0.09 \\
\hline
\end{tabular}


There is no general common behaviour found between all probability statuses of inflation variable exhibited in Table 9 probability and the bank stocks included in the study. In case the probability of decreasing inflation is $100 \%$, probability of maintaining all bank stocks on average level increases. However, in case of the probability of increasing inflation is $100 \%$, it could be seen that probability of increasing returns on GARAN and AKBNK stocks increase, as the probability of decreasing returns on ISCTR and YKBNK stocks increases.

Table 10. The Impact of Entry of New Evidence into USD/TRY Exchange Rate Macroeconomic Factor on Expected Returns on GARANTI BANK, AKBANK, IS BANK and YAPI KREDI BANK Stocks

\begin{tabular}{|c|c|c|c|c|c|c|}
\hline & State & $\begin{array}{l}\text { Entering } \\
\text { Evidence }\end{array}$ & GARAN State & $\begin{array}{c}\text { Before Adding } \\
\text { Evidence (GARAN) }\end{array}$ & $\begin{array}{l}\text { After Adding Evidence } \\
\text { (GARAN) }\end{array}$ & $\begin{array}{c}\text { GARAN } \\
\text { Change (\%) }\end{array}$ \\
\hline \multirow{10}{*}{ USD/TRY } & \multirow{3}{*}{ Low } & \multirow{3}{*}{$\% 100$} & Low & 32.20 & 32.34 & 0.14 \\
\hline & & & Medium & 37.01 & 37.04 & 0.03 \\
\hline & & & High & 30.79 & 30.61 & -0.18 \\
\hline & \multirow{3}{*}{ Medium } & \multirow{3}{*}{$\% 100$} & Low & 32.20 & 31.84 & -0.36 \\
\hline & & & Medium & 37.01 & 36.99 & -0.02 \\
\hline & & & High & 30.79 & 31.16 & 0.37 \\
\hline & \multirow{3}{*}{ High } & \multirow{3}{*}{$\% 100$} & Low & 32.20 & 32.14 & -0.06 \\
\hline & & & Medium & 37.01 & 36.89 & -0.12 \\
\hline & & & High & 30.79 & 30.97 & 0.18 \\
\hline & State & $\begin{array}{l}\text { Entering } \\
\text { Evidence }\end{array}$ & $\begin{array}{l}\text { AKBNK } \\
\text { State }\end{array}$ & $\begin{array}{c}\text { Before Adding } \\
\text { Evidence (AKBNK) }\end{array}$ & $\begin{array}{l}\text { After Adding Evidence } \\
\text { (AKBNK) }\end{array}$ & $\begin{array}{c}\text { AKBNK } \\
\text { Change (\%) }\end{array}$ \\
\hline \multirow{10}{*}{ USD/TRY } & \multirow{3}{*}{ Low } & \multirow{3}{*}{$\% 100$} & Low & 33.63 & 33.45 & -0.18 \\
\hline & & & Medium & 38.24 & 39.01 & 0.77 \\
\hline & & & High & 28.13 & 27.53 & -0.6 \\
\hline & \multirow{3}{*}{ Medium } & \multirow{3}{*}{$\% 100$} & Low & 33.63 & 34.24 & 0.61 \\
\hline & & & Medium & 38.24 & 37.16 & -1.08 \\
\hline & & & High & 28.13 & 28.61 & 0.48 \\
\hline & \multirow{3}{*}{ High } & \multirow{3}{*}{$\% 100$} & Low & 33.63 & 33.45 & -0.18 \\
\hline & & & Medium & 38.24 & 36.28 & -1.96 \\
\hline & & & High & 28.13 & 30.27 & 2.14 \\
\hline & State & $\begin{array}{l}\text { Entering } \\
\text { Evidence }\end{array}$ & $\begin{array}{l}\text { ISCTR } \\
\text { State }\end{array}$ & $\begin{array}{l}\text { Before Adding } \\
\text { Evidence (ISCTR) }\end{array}$ & $\begin{array}{l}\text { After Adding Evidence } \\
\text { (ISCTR) }\end{array}$ & $\begin{array}{c}\text { ISCTR } \\
\text { Change (\%) }\end{array}$ \\
\hline \multirow{10}{*}{ USD/TRY } & \multirow{3}{*}{ Low } & \multirow{3}{*}{$\% 100$} & Low & 31.62 & 30.86 & -0.7 \\
\hline & & & Medium & 37.56 & 38.69 & 1.28 \\
\hline & & & High & 30.82 & 30.45 & -0.58 \\
\hline & \multirow{3}{*}{ Medium } & \multirow{3}{*}{$\% 100$} & Low & 31.62 & 33.50 & 1.94 \\
\hline & & & Medium & 37.56 & 33.87 & -3.54 \\
\hline & & & High & 30.82 & 32.62 & 1.59 \\
\hline & \multirow{3}{*}{ High } & \multirow{3}{*}{$\% 100$} & Low & 31.62 & 31.62 & 0.06 \\
\hline & & & Medium & 37.56 & 37.28 & -0.13 \\
\hline & & & High & 30.82 & 31.10 & 0.07 \\
\hline & State & $\begin{array}{l}\text { Entering } \\
\text { Evidence }\end{array}$ & $\begin{array}{l}\text { YKBNK } \\
\text { State }\end{array}$ & $\begin{array}{l}\text { Before Adding } \\
\text { Evidence (YKBNK) }\end{array}$ & $\begin{array}{l}\text { After Adding Evidence } \\
\text { (YKBNK) }\end{array}$ & $\begin{array}{c}\text { YKBNK } \\
\text { Change (\%) }\end{array}$ \\
\hline \multirow{9}{*}{ USD/TRY } & \multirow{3}{*}{ Low } & \multirow{3}{*}{$\% 100$} & Low & 26.77 & 24.56 & -2.21 \\
\hline & & & Medium & 39.57 & 41.23 & 1.66 \\
\hline & & & High & 33.66 & 34.21 & 0.55 \\
\hline & \multirow{3}{*}{ Medium } & \multirow{3}{*}{$\% 100$} & Low & 26.77 & 30.35 & 3.58 \\
\hline & & & Medium & 39.57 & 36.84 & -2.73 \\
\hline & & & High & 33.66 & 32.81 & -0.85 \\
\hline & & & Low & 26.77 & 31.48 & 4.71 \\
\hline & High & $\% 100$ & Medium & 39.57 & 36.12 & -3.45 \\
\hline & & & High & 33.66 & 32.41 & -1.25 \\
\hline
\end{tabular}


Table 10 exhibits the relationship between returns on bank stocks USD/TRY currency exchange rate variable. Findings suggest that there is no significant correlation between returns on bank stocks and USD/TRY exchange rate. In the theoretical aspect, a negative correlation is expected between currency variable and stocks returns. However, according to our analysis results, when the probability of decreasing USD/TRY exchange rate is $100 \%$, the probability of maintaining returns on AKBNK, ISCTR and YKBNK stocks on average level increases. On the other hand, it could be seen that the probability of decreasing return on GARAN stock increases. Although the probability of high return for GARAN, AKBNK, and ISCTR returns increases in case of certain possibility for rising USD Exchange rate, vice versa case for YKBNK returns. Based on the models, it could be suggested in general that returns on bank stocks exhibit the same movement pattern with the currency rate. It indicates that foreign investors' proportion among the overall investors of the relevant stocks could be higher.

\section{Conclusions}

In parallel with the recent technological advancements, a global investment network in which investors are capable of creating portfolios that never sleep emerged. In such an investment environment, using correlation or linear models as tools to determine equities to include investor portfolios might be insufficient. Especially the need for developing flexible strategies to adopt market conditions changing with great pace places investors in a position which necessitates them to use diverse information and techniques. At this point, the models structured by Bayesian networks introduce a different point of view to the correlation relationship in the modern portfolio theory. Bayesian network models are capable of providing a probability relationship between equities and macroeconomic factors in visual form; moreover, when new information has arrived, it is possible to update stocks return values in the network simultaneously. In this way, flexible and dynamic information needed by investors could be provided.

The objective of the present study is to provide dynamic information needed by investors through Bayesian networks and to investigate and model the relationship between macroeconomic indicators and returns on bank stocks based on the Arbitrage Pricing Model (APT). In line with the objective of the study, dynamic relationships between macroeconomic factors and monthly returns of the stocks of four banks traded uninterruptedly in the BIST National 100 Index by employing Bayesian network models for the period of June 2001-January 2017.

Prior to the modeling stage of the analysis, all series are required to be discretized into three statuses (states) according to the K-means data clustering algorithm. Then, based on the stocks return APT model of each bank, macroeconomic indicators are associated, and each factor was entered hard evidence so as to acquire relevant resultant finding from dynamic relationships.

Findings acquired through Bayesian network models reveal the dynamic relationship of returns on Garanti Bank, Akbank, Is Bank and Yapi Kredi Bank stocks. Whereas the coefficients estimated by the OLS estimator were found to be statistically insignificant except the variable of XU100 Index, the models structured through Bayesian networks provided more detailed information. Our findings suggested that macroeconomic indicators created different impacts on returns on four banks' stocks. In general, returns on Yapi Kredi Bank stock display notably different probabilistic behavior with respect to other banks' stocks.

In the model in which especially investigated the relationship between XU100 and returns on all stocks, it could be clearly seen that Bayesian network models could provide more detailed information to investors regarding the relationship between stock and market return in comparison with beta coefficients obtained from the market model. Whereas the market model can estimate only a single financial beta coefficient, the Bayesian network model could provide different probability estimations in detail with respect to different market states. When the relationship between money supply and return on bank stocks is investigated, it was determined that probability fluctuations related with movement in M2 money supply in either direction have a different consequence on each stock. It was considered this status is a result of varying liquidity positions of individual banks. Results indicated that different cash positions are effective on profitability levels on banks, and this is effective on their market values. In the detailed investigation of the 
relationship between interest rate and returns on bank stocks, it was determined that each bank could be influenced differently from the changes in interest rates. In theory, an inverse relationship is expected between the interest rate and returns on stocks. However, the fact that stocks included in the study were from the banking industry means that their profitability would increase in case of increasing interest rate. Therefore, the probability of increasing returns on bank stocks in the scope of the study increases when the probability of increasing interest rate is $100 \%$. As a preliminary expectation of the study, the bank stocks' returns were not influenced by changes in oil prices since they are not manufacturing companies. The estimations results based on Equation 4 give statistically insignificant; however, there is a relationship on weak levels of probability by Bayesian network models. In case of hard evidence state in which the probability of increasing inflation rate is $100 \%$, no common behavior pattern was determined between returns on bank stocks and inflation rate. However, in the case of the probability of decreasing inflation rate was $100 \%$, it was seen that the probability of maintaining all returns on bank stocks at the same level increased. In theory, a negative relationship was expected between currency rate and return on bank stocks. However, based on the models structured, while currency variable of USD/TRY exchange rate is expected to increase for sure, an increase was determined with the probability of increasing returns on majority of bank stocks. It was considered as the reason for this behavior that majority of investors of bank stocks was constituted of foreign investors.

Finally, instead of managing portfolios relying on a single correlation or regression coefficient, investors could access different relationship probabilities for three different states obtained through the Bayesian network model. This capability provides highly detailed visibility of the dynamics among stocks. Moreover, the capability of Bayesian network models to accept new information entry at any time allows investors to follow up correlations more dynamically in comparison with conventional analysis methods.

\section{Acknowledgments}

We are grateful to the editor and three anonymous referees for many helpful comments and suggestions; though the remaining shortcoming of the paper are solely ours.

\section{References}

Alizadeh, N. (2013). Analysing the impact of macro economical data on the stock returns of oil and natural gas in Turkey by using arbitrage pricing model. Hacettepe University, Master's Thesis, Turkey.

Altay, E. (2005). The effect of macroeconomic factors on asset returns: A comparative analysis of the German and the Turkish stock markets in an APT framework. Marmara Universitesi Sosyal Bilimler Enstitusu Dergisi, 6(23), $217-$ 237.

BAT, (2017, August). The banking system in Turkey yearly statistics: 1959 - 2016. The Banking Association of Turkey Report, Turkey.

Beenstock, M., \& Chan, K. (1988). Economic forces in the London Stock Market. Oxford Bulletin of Economics and Statistics, 50(1), 27-39.

Bensi, M. T., Kiureghian, A. D., \& Straub, D. (2011). A Bayesian network methodology for infrastructure seismic risk assessment and decision support. Pacific Earthquake Engineering Research Center.

Burmeister, E., \& McElroy, M. (1988). Joint estimation of factor sensitivities and risk premia for the Arbitrage Pricing Theory. Journal of Finance, 43(3), 721-733.

Burmeister, E., \& Wall, K. D. (1986). The Arbitrage Pricing Theory and macroeconomic factor measures. Financial Review, 21(1), 1-20.

Chan, K., Chen, N., \& Hsieh, D. (1985). An exploratory investigation of the firm size effect. Journal of Financial Economics, 14, 451-71.

Chen, N., Roll, R., \& Ross, S. (1986). Economic forces and the stock market. The Journal of Business, 59(3), 383-403. 
Chen, S., \& Jordan, B. (1993). Some empirical tests of the Arbitrage Pricing Theory: Macrovariables vs. derived factors. Journal of Banking and Finance, 17, 65-89.

Clare, A. D., \& Thomas, S. H. (1994). Macroeconomic factors, the APT and the UK stock market. Journal of Business Finance and Accounting, 21, 309-330.

Conrady, S., \& Jouffe, L. (2015). Bayesian Networks \& BayesiaLab-A practical introduction for researchers. USA: Bayesia.

Demirer, R., Mau, R., \& Shenoy, C. (2006). Bayesian networks: A decision tool to improve portfolio risk analysis. Journal of Applied Finance, 16(2), 106-133.

Elton, E. J., \& Gruber, M. J. (1981). Modern portfolio theory and investment analysis. New York: John Wiley and Sons.

Greppi, A. (2014, June-July). A Bayesian network approach to portfolio management. First DREAMT Research in Progress Workshop, 83-92, Pavia.

Greppi, A., De Giuli, M. E., \& Tarantola, C. (2013, October). Bayesian network for stock picking. Conference presentation at $10^{\text {th }}$ Scientific Meeting of Classification and Data Analysis Group, Cagliari.

Hoe, T. K. (2014). A machine learning-based decision support tools for portfolio risk analysis. Universiti Tunku Abdul Rahman, Master's Thesis.

Kearney, C., \& Daly, K. (1998). The causes of stock market volatility in Australia. Applied Financial Economics, 8, 597605.

Kwon, C. S., \& Shin, T.S. (1999). Cointegration and causality between macroeconomic variables and stock market returns. Global Finance Journal, 10(1), 71-81.

Lauria, E. J. M., \& Duchessi, P. (2007). A methodology for developing Bayesian networks: An application to information technology (IT) implementation. European Journal of Operational Research, 179, 234-252.

Market, M. (2018). The Turkish banking sector: A promising market? Retrieved February 20, 2018, from themarketmogul.com/turkish-banking-sector

Markowitz, H. (1952). Portfolio selection. The Journal of Finance, 7(1), 77-91.

Mittal, A., Kassim, A., \& Tan, T. (2007). Bayesian network technologies: Applications and graphical models. USA: IGI Global.

Mrad, A. B., Delcroix, V., Maalej, M. A. \& Abid, M. (2012). Understanding soft evidence. The Sixth European Workshop on Probabilistic Graphical Models (PGM 2012), 19-21 September, Granada, Spain.

Nagarajan, R., Scutari, M., \& Lebre, S. (2013). Bayesian networks in R with applications in systems biology. New York: Springer Science+Business Media.

Olbryś, J. (2009). Forecasting portfolio return based on Bayesian network model. In W. Milo, G. Szafrański, \& P. Wdowiński (eds.) Financial Markets. Principles of Modelling, Forecasting and Decision-Making, FindEcon Monograph Series: Advances in Financial Market Analysis, Volume 7, Lodz University Press, 157-171.

Ozer, O., Kaya, A., \& Ozer, N. (2011). Hisse senedi fiyatlari ile makroekonomik degiskenlerin etkilesimi. Dokuz Eylul Universitesi Iktisadi ve Idari Bilimler Fakultesi Dergisi, 26(1), 163-182.

Ozkan, N., Cakan, S., \& Kayacan, M. (2017). Intellectual capital and financial performance: A study of the Turkish banking sector. Borsa Istanbul Review, 17(3), 190-198.

Sammut, C., \& Webb, G. I. (2011). Encyclopedia of machine learning. Springer.

Shenoy, C., \& Shenoy, P. P. (1998). Bayesian networks: A decision tool to improve portfolio risk analysis. Working Paper, School of Business, University of Kansas.

Sucar, L. E. (2015). Probabilistic graphical models principles and applications. London: Springer-Verlag.

Trucco, P., Cagno, E., Ruggeri, F., \& Grande, O. (2008). Bayesian belief network modelling of organisational factors in risk analysis: A case study in maritime transportation. Reliability Engineering and System Safety, 93, 823-834.

Tseng, C. (2003). Comparing artificial intelligence systems for stock portfolio selection. Retrieved July 24, 2017, from http://depts.washington.edu/sce2003/Papers/236.pdf

Valtorta M., Kim Y., \& Vomlel J. (2002). Soft evidential update for probabilistic multiagent systems. International Journal of Approximate Reasoning, 29(1), 71-106.

Villa, S., \& Stella, F. (2012). Bayesian networks for portfolio analysis and optimization. Financial Decision Making Using Computational Intelligence, 70, 209-232.

Zuo, Y., \& Kita, E. (2012). Up/down analysis of stock index by using Bayesian network. Engineering Management Research. 1(2), 46-52. 